\title{
The Europeanization process and Kurdish nationalism in Turkey: the case of the Democratic Society Party
}

\author{
İbrahim Saylan
}

To cite this article: Ibrahim Saylan (2012) The Europeanization process and Kurdish nationalism in Turkey: the case of the Democratic Society Party, Nationalities Papers, 40:2, 185-202, DOI: 10.1080/00905992.2011.652608

To link to this article: http://dx.doi.org/10.1080/00905992.2011.652608

曲 Published online: 12 Apr 2012.

Submit your article to this journal $\widetilde{ }$

Џلll Article views: 363

Q View related articles $\square$

Citing articles: 3 View citing articles 5 


\title{
The Europeanization process and Kurdish nationalism in Turkey: the case of the Democratic Society Party
}

\author{
İbrahim Saylan* \\ Department of Political Science, Bilkent University, Ankara, Turkey
}

(Received 16 October 2010; final version received 12 December 2011)

\begin{abstract}
This study aims at analyzing the impact of the European integration process on Kurdish nationalism in Turkey by focusing on the Democratic Society Party (Demokratik Toplum Partisi, DTP) as the major pro-Kurdish political party in Turkey between 2005 and 2009. It argues that the Europeanization process in Turkey, which accelerated in the post-Helsinki period, has brought about some important consequences concerning the recognition and expression of Kurdish identity. The study examines Europe's impact on the DTP through analysis of party documents and interviews with party representatives, in order to investigate the meaning and use of the European integration process in the DTP's sub-state nationalist ideology. This analysis shows that, although the Europeanization process in Turkey has somewhat broadened opportunity structures for Kurdish sub-state nationalist politics, overall the EU's impact on the DTP's nationalist politics has remained indirect and limited.
\end{abstract}

Keywords: DTP; Kurdish nationalism; opportunity structures; European integration

Sub-state nationalism has become one of the most remarkable political forces in the contemporary world, especially in the European context. The European integration process, together with the processes of globalization, has significantly contributed to the rise of sub-state nationalism. In this process, the opportunity structures that determine the resources for and constraints on sub-state nationalist political activism have been reshaped, mainly due to the transformation of the nation-state and the emergence of new channels for regional assertiveness that are also utilized by sub-state nationalist political actors. Sub-state nationalist actors, specifically political parties, have found the process of European integration highly supportive for their purposes. European integration has not only eroded the host states that are their main rivals in the nationalist struggle, but it is also resulting in a reformation of Europe's political structure (Guibernau; Csergo and Goldgeier). Therefore, almost all sub-state nationalist parties in Europe have adopted a pro-European stance, reformulating their discourse and identity to make use of these new opportunity structures. More critically, they have come to frame their ultimate goals in European terms, either as a "Europe of the regions" or "independence in Europe." As a result, the European integration process has brought about significant effects on sub-state nationalist political parties.

Kurdish sub-state nationalism in Turkey has also been affected by the European integration process. EU-anchored democratization reforms in Turkey, which has been trying to fulfill the Copenhagen criteria for full EU membership, have provided Kurdish

\footnotetext{
*Email: isaylan@bilkent.edu.tr
} 
nationalists with new channels of influence. Different strands of Kurdish nationalism have sought to make use of the process to promote their nationalist cause. Interestingly, these efforts have thus far received little scholarly attention. When not being investigated as a case study in itself, Kurdish nationalism has generally been studied as a problem of terrorism threatening Turkey's domestic political stability while badly affecting the Turkish state's relations with the international community, particularly the EU. In order to shed light on the impact of the European integration process on Kurdish nationalism in Turkey, this paper focuses on the Democratic Society Party (Demokratik Toplum Partisi, DTP) as the major political representative of Kurdish nationalism between 2005 and 2009. Within the broader picture of the interaction between sub-state nationalisms, nation-states and EU integration, it analyzes the impact of the integration process on the DTP in terms of national identity construction, definition of goals, and choice of strategies. Such an effort can also contribute to our knowledge of what happens to sub-state nationalisms within the European integration process.

\section{The European integration process as an opportunity structure}

Sub-state nationalism is a broad category that describes movements and political parties claiming the right to self-government within a demarcated territory ("homeland"), basically derived from the assertion of distinct ethnic/cultural identity and a common past - real or invented. Self-government itself generally refers to a kind of autonomy, ranging from cultural rights to total independence (Beland and Lecours).

The fundamental claim of the initiators and supporters of this type of nationalism is that state power is monopolized by a larger, dominant ethnic group, while their ethnic group (which they claim to be a "nation") is represented inadequately or not at all in the existing political structure (Catt and Murphy 18). Sub-state nationalists therefore organize themselves as social movements and political parties, adopting violent or nonviolent strategies, to challenge the existing state structure and the prevailing definition of national identity. In this sense, it has a more oppositional characteristic than other forms of nationalism. Nevertheless, like other forms of nationalism, it can be viewed as a form of politics that seeks to maintain or gain the power that has come to be concentrated in the state in modern times (Breuilly). Sub-state nationalism, as a form of politics centered on the politicization of ethnicity, has emerged as a response to changing circumstances, generally the centralizing and homogenizing efforts of nation-states, and the conflictual consequences of modernization that can lead to a growth in ethnic awareness (Newman).

In the emergence and development of sub-state nationalism, elites play a pivotal role in terms of the politicization of ethnic identities and mobilization of the masses. Nevertheless, a political approach to sub-state nationalism should not understate the role of institutions, specifically those of the state, which, to a large extent, shapes the structure in which sub-state nationalist movements emerge and develop (Lecours). For this reason, this paper adopts a political approach that focuses on opportunity structures, which provides a valuable theoretical framework to explore the impact of European integration on sub-state nationalism, as well as the emergence and development of sub-state nationalist challenges. Each sub-state nationalism is born into a particular context that not only influences the way it emerges, but also defines the limits of opportunity structures for sub-state nationalist political struggle and the strategies it can make use of. At the same time, a political approach to sub-state nationalism based on analysis of opportunity 
structures sheds light on their use in the process of the mobilization and framing of nationalist discourse by sub-state nationalist political parties.

The opportunity structure model, specifically the political opportunity model, as one of the best-known models in the literature of social movements, includes only exogenous factors that limit or empower oppositional collective actors (McAdam et al.; Tarrow). This study, however, adopts a much broader framework, suggesting that an opportunity structure includes the broader political environment in which sub-state nationalist politics is embedded, and that it describes the distribution and structuring of internal and external resources and constraints that make nationalist mobilization and activity more or less likely (Hooghe 31). These resources and limitations are politically, economically, socially, and culturally defined. That is, an opportunity structure is not only characterized in politico-institutional terms, but also includes economic and normative/moral aspects that are ethno-culturally framed in nationalist discourse. It has two main interlocked dimensions: internal and external.

In analyzing sub-state nationalist movements and parties, the internal dimension corresponds to endogenous factors such as the strength of ethnic identity, the political program and policy stances, organizational capacity, leadership, the existence of debilitating intra-party cleavage, financial and human resources, links with social movements and voters, and media coverage (De Winter 222-35; Van Houten 16). The external dimension includes national (state) and international (extra-state) factors, also termed environmental or exogenous factors. National and international factors interact with each other in a dynamic atmosphere, which influences the opportunity structure for sub-state national mobilization. The most critical national factor in shaping the opportunity structure is the political regime, with its constitution, party system, and electoral system. ${ }^{1}$

International factors, a major exogenous influence, consist of the changed nature of international systems, the development of supranational organizations, and the demonstration effect of sub-state nationalist movements in other countries. While this is not an exhaustive list, it includes some of the most important factors that shape opportunity structures. Such environmental factors are of critical significance, since they together substantially affect the prospects for sub-state nationalist movements.

Beyond these factors, however, a reliable analysis of sub-state nationalism should not overlook the significance of critical events and issues for sub-state nationalist mobilization and activity. According to Birch (72), "eruptive" or "fomenting factors," by instigating sub-state nationalist conflict, are vital to capture mass support. Fomenting factors, serving as economic, political and ideological resources, may be positive or negative social, economic or political changes. For instance, within the context of Turkey's Kurdish case, the increased repression of Kurdish nationalist movements following the 1980 military coup was a significant factor fomenting Kurdish sub-state nationalist mobilization and activity. ${ }^{2}$

In short, a focus on opportunity structure can be considered to be valid for at least two reasons. First, through its political, economic and moral/normative dimensions, the opportunity structure model acknowledges how, to a great extent, the environment within which sub-state nationalism develops is determined by the state, which still constitutes the center of power resources, albeit remarkably transformed due to integrative processes. Second, this model allows for the inclusion of an extra-state dimension into the analysis, thereby recognizing the impact of contemporary events and politically or economically integrative forces on sub-state nationalist movements. 


\section{The significance of the European integration process as an opportunity structure}

A great majority of sub-state nationalist parties today have a pro-EU stance, since they conceive of European integration as a process reshaping opportunity structures to their advantage in two main ways. First, the emergence and development of the EU, the most remarkable and current form of European integration, as a supranational organization has changed the nature of the national dimension of opportunity structures by transforming the nation-state. Second, sub-state nationalist parties see the EU as a polity-making actor that expands opportunity structures to their advantage by forming new institutions and programs, providing funds, and enabling transnational alliances across the European continent.

It is clear that nationalism has proliferated and undergone significant changes within the European integration process (Csergo and Goldgeier), and sub-state nationalist parties have made use of the new advantageous opportunity structures in many respects. Yet, the potential and impact of these new structures should not be exaggerated. It is true that sovereignty is no longer undivided and that territorial borders have become porous, but power continues to lie primarily with the nation-state (Mann; Suny). Regional governments, some of which are controlled by sub-state nationalist parties (e.g. the Scottish National Party in Scotland), have only been able to influence Europe if they have power in their host states, since access to power occurs through, rather than beyond, the nation-state. Furthermore, as long as member states are "masters of the treaty," the EU should not be expected to develop a common policy or perspective on the "nationalities question," which is still primarily a national question. This means that, while nation-states have undergone a transformation within the European integration process, they still persist, so the main location of subnationalist power struggles remains the state because, as a form of politics, sub-state nationalism seeks power for the ethno-cultural group it seeks to represent. While full sovereignty may not make sense in the new context, independent statehood still matters. As long as nationalist politics, grounded in conflicts of identity and interests, exist, it is always possible that ethno-culturally distinct groups without states will pursue some kind of autonomy, ranging from cultural autonomy to full independence. That is, there is no guarantee that they will be satisfied with an institutional structure falling short of independence. At the same time, though, full independence may be a sincerely declared and pursued ultimate goal, or just a trump card against the nation-state. Nevertheless, independent statehood remains an appealing option, insofar as nation-states are tenacious and a "Europe of the regions" is a far-fetched ideal.

Currently, therefore, the realization of sub-state nationalist ideals depends on a continuous struggle against the nation-state and its officially constructed and reproduced nationalism. Within the politics of nationalism, European integration functions mainly as an external support system that provides sub-state nationalist parties with a more supportive framework than the exclusively nationally defined opportunity structures of the past.

Kurdish nationalism in Turkey has not been free from the effects of these new dynamics, especially considering the Europeanization process carried out through reform packages in Turkey. The next section analyzes effects of the Europeanization process on the Kurdish question on which Kurdish nationalism is based.

\section{The Turkish nation-state, the EU, and the Kurdish question in the post-Helsinki period}

Since the founding of the Turkish Republic in 1923, Kurdish nationalism has been one of the most significant challenges to the state's aim to create an organic, homogeneous 
national society. A sense of Kurdish nationalism has been nurtured by the ethno-political Kurdish question, ${ }^{3}$ as a consequence of the denial and suppression of Kurdish identity by the Turkish state (Cornell). While the opportunity structures for Kurdish nationalism were highly restrictive for decades, democratization reforms initiated in the post-Helsinki period, especially between 2002 and 2005, have provided the Kurdish nationalist movement with new opportunities for promoting the recognition of Kurdish identity by broadening the political system and enabling Kurdish nationalism to compete with various forms of Turkish nationalism, including the official state version.

The post-Helsinki period has been significant in many respects, since the acceptance of Turkey's candidacy for EU membership at the Helsinki summit in 1999 marked a "categorical jump" regarding Turkey's relations with the EU. In addition to that, the cessation of large-scale violence after the capture of PKK leader Öcalan provided Turkey with a new opportunity to handle the Kurdish question in a non-military way. ${ }^{4}$ Thus, the Turkish government introduced a series of constitutional amendments and harmonization packages in order to fulfill the Copenhagen political criteria. ${ }^{5}$ While the accession process has proved to be a key anchor in supporting democratization and modernization in Turkey, this "unprecedented" reform process has also brought about remarkable improvements regarding the recognition of Kurdish identity. ${ }^{6}$ The third reform package of August 2002 made particularly crucial changes by allowing teaching of Kurdish in private institutions and broadcasting in languages other than Turkish (Ulusoy). Moreover, in 2002, Turkey ended emergency rule in its largely Kurdish southeastern provinces, and ratified certain parts of the international law dealing with minority rights and cultural rights. ${ }^{7}$ This period also witnessed the start of broadcasting in Kurdish by the state TV channel (TRT) in 2004. Even though this was for no more than half an hour a day, its symbolic importance was very significant. These openings have been recently followed by the establishment of 24-hour broadcasting on a new Kurdish-language state TV channel (TRT 6), and the opening of a Kurdish language department at Mardin Artuklu University. ${ }^{8}$

As Turkey has undergone an unprecedented and profound transformation in the postHelsinki period, the EU has played an anchoring role as an external support system. There is no doubt that both the EU's severe criticisms of Turkey's previous insistence on a military solution to the Kurdish question, and its imposition of political criteria to be met for Turkey to start accession negotiations, have been influential factors that forced or encouraged Turkey towards democratization. Yet this is not to suggest that the EU has or could act as the principal, let alone the only determinant of the transformation of the Kurdish question. Rather, domestic factors have been the main determinants of change. First, by forcing the PKK to suspend armed conflict with Turkish security forces, the capture of Öcalan provided a somewhat more appropriate context for democratization reforms, particularly regarding the Kurdish issue. Secondly, the election in November 2002 of the AKP (Adalet ve Kalkinma Partisi or Justice and Development Party), a "pragmatic-conservative and Islam-sensitive party" (Cizre 1), finally provided Turkey with a single-party government with a clear parliamentary majority following a decade of fragile coalitions. Supporting a civic conception of nationalism, the AKP government has argued for a redefinition of Turkish national identity without any ethnic connotations. Thirdly, a thriving civil society has contributed to the reform process by opening various channels of dialog for the expression of different aspects of the Kurdish question.

Within this process, compared to the influence of domestic factors, the impact of the EU on the efforts for a reconceptualization of the Kurdish question has been limited, and the EU's proposals for a solution to the Kurdish question have remained rather vague (Tocci, "Europeanization in Turkey"). Beginning with its 1998 Progress Report, the 
Commission has called for a "political and non-military solution to the problem of the southeast," without specifying what such a solution entailed. Instead, it simply stated that "a civil solution could include the recognition of certain forms of Kurdish cultural identity and greater tolerance of the ways of expressing that identity, provided they do not advocate separatism or terrorism" (Tocci, "The Europeanization of Turkey's Kurdish Question" 122). The EU's concrete proposals for the solution of the Kurdish question have faced two main problems. First, any EU proposal is made within the scope of its approach to the protection of minority rights, ${ }^{9}$ and both the Turkish state and Kurdish nationalist have opposed this, albeit for different reasons. According to the Turkish state, minority groups in Turkey were determined by the Treaty of Lausanne in 1923, so any attempt to define the Kurds as a minority is artificial and malicious. Kurdish nationalists, meanwhile, wish to be defined as one of the constitutive elements of the Turkish state, rather than as just a minority group. Second, the EU sees states as monolithic political entities that cannot be obliged to sign up to international treaties or conventions related to minority rights. That is, the EU lacks the legal power to compel a state to recognize any minorities within its boundaries, ${ }^{10}$ and it is also difficult for the EU to uphold a common policy on minorities or sub-national groups, since the issue of national minorities is still overwhelmingly "national." In this sense, the idea of state rights remains intact, and the principle of state sovereignty can be still used to make persuasive arguments against national minority rights (Jackson Preece 173).

Turkey's official view of the Kurdish issue has changed from denial to recognition of Kurdish identity, even if this is not yet constitutionally entrenched, and EU-anchored democratization reforms have significantly contributed to this process. However, the EU's efforts to categorize the Kurdish question within the normative framework of minority rights have been rejected by both Turkish and Kurdish parts for different reasons. Changes in the official view of the Kurdish question and democratization reforms have relatively broadened the opportunity structures for Kurdish nationalists, but legal Kurdish politics still faces significant obstacles. For instance, according to the Law on Political Parties, the use of languages other than Turkish remains illegal in political life. In addition, even when they are not engaged in violent activities and do not extol violence, political parties still run the risk of dissolution. Equally importantly, for regionally-based Kurdish parties, the $10 \%$ national election threshold to enter the Turkish Parliament still constitutes a huge obstacle to a just representation system.

The next section focuses on the impact of European integration on Kurdish sub-state nationalism through an analysis of the DTP as the major legal political party of Kurdish nationalism between 2005 and 2009. It explores the impact of the European integration process on various aspects of the DTP, taking into consideration the party's uneasy interaction with the Turkish state and Turkish nationalism.

\section{The DTP: identity, goals, strategies and ideology}

Turkish modernization has led to seemingly contradictory consequences: on the one hand, it has contributed to a growing awareness of Kurdish identity among Kurds; on the other hand, it has promoted the integration of Kurds with other ethnic groups in Turkey (Akyol). Thus, although the great majority of Kurds have become integrated with the rest of the country, mainly due to internal migration and interethnic marriages, it has also gradually become an open secret that today it is impossible to assimilate the Kurds into Turkishness (Oran). Kurdish ethnic demands have, to a great extent, been kept alive by Kurdish nationalism over four broad phases since the early republican period (Yavuz and Günter). While 
Kurdish nationalism dates back to the nineteenth century, and had an ethno-religious character in the 1920s and 1930s, it appeared as a modern nationalist movement in the 1960s, before turning into a mass movement in the 1980s (McDowall). The post-1980 phase has witnessed the acceleration of Kurdish identity formation, mainly due to state repression, long-term mobilization and the Kurdish diaspora in Europe (Bozarslan; Hirschler). ${ }^{11}$ Although there have always been alternative voices within it, Kurdish nationalism in Turkey has been dominated by the PKK (Partiya Karkaren Kurdistan, or Kurdish Workers Party) since the early 1980s.

The PKK's stated aim in the past was to create an independent Kurdish state of Kurdistan, to consist of parts of southeastern Turkey, northeastern Iraq, northeastern Syria and northwestern Iran. Its original ideological foundation was a combination of Marxism-Leninism and nationalism (Gürbey and İbrahim), although it somewhat reduced its emphasis on Marxism after the fall of the Soviet Union. In recent years, its focus has shifted from ethnic secessionism to obtaining equal cultural and democratic rights, and the recognition of Kurdish identity in the Turkish Constitution (Özcan). Nevertheless, although its principal goal seems to have shifted from achieving a separate Kurdish state to "democratization of the Turkish Republic," it has never relinquished the strategy of violence. Apart from the violent actions of the PKK, the PKK-linked political parties have, since the early 1990s, sought to persuade the state to recognize Kurdish identity, and accordingly restructure the political system.

The DTP, founded in 2005 as the latest in the chain of Kurdish nationalist parties before the current Peace and Democracy Party (Barış ve Demokrasi Partisi, BDP), has been linked to the PKK. It emerged from the merger of the Democratic People's Party (Demokratik Halk Partisi, DEHAP) and the Democratic Society Movement (Demokratik Halk Hareketi, DTH). The DTH was founded by Leyla Zana, Orhan Doğan, Selim Sadak, and Hatip Dicle, who were all imprisoned between 1994 and 2004 for their pro-Kurdish nationalist activities ("Pro-Kurdish politics"). By incorporating DEHAP, which dissolved itself in order to join the DTP, the DTP aimed at a broad participation of all those Kurdish nationalists willing to endorse a new democratic autonomy project. Although the DTP presented itself as a nation-wide party, it was principally a regional party, in terms of both the focus of its program and its popular electoral support. ${ }^{12}$ It was the dominant political representative of the Kurdish nationalist movement until its dissolution in $2009 .{ }^{13}$

Deliberately rejecting the use of the concept of nation, the DTP instead asserted that the "40 million-strong Kurdish people," primarily living in four countries, constitutes one of the historical peoples of the Middle East. ${ }^{14}$ Kurdish history and culture, and especially Kurdish as an Indo-European language, are considered to be the main elements of a distinct Kurdish identity. Against the Turkish state's systematic policy of denial of the existence of a Kurdish ethnic group, the Kurdish national community has been historicized through ethno-historical myths, especially regarding the pre-Islamic period. ${ }^{15}$ The DTP has strongly emphasized and used language and festivals such as Newroz as ethnic boundary markers. ${ }^{16}$ Since Kurdish nationalism emerged as a reaction to assimilation, the ethnic color of Kurdish national identity has become more obvious. Nevertheless, this has not led the DTP to support an exclusive definition of Kurdishness. Rather, the DTP has pursued an official recognition of Kurdish ethnic identity and accepted Türkiyelilik ("being a member of Turkey") as a politico-territorial supra-identity that can cover all ethnic groups living in Turkey. Regarding the identity issue, the territorial dimension of Kurdish identity is a contested issue. In particular, the "map dispute" over the territorial boundaries of the "Kurdish homeland" has been part of the autonomist claims of the nationalist struggle. ${ }^{17}$ 
The DTP's sub-state nationalism can be specified more closely by taking into consideration its social democratic position. As an observer political party to the Socialist International and the Party of European Socialists, the DTP has combined traditional nationalist policies of self-government with a post-industrial agenda. Positive discrimination for women, the protection of the ecological balance, and sustainable economic development were some of the party's polices reflecting its left-of-center position (DTP, Party Program).

In terms of its political goals, the DTP's specificity compared with its predecessors lies in the policy of "democratic autonomy" that was entrenched in the party's regulations in 2007. According to the DTP, the Kurdish question arose because the Turkish Republic denied its foundational principles with the 1924 Constitution, in which the Republic denied its actual ethnic and religious diversity for the sake of creating a homogeneous Turkish nation, although it had been founded through a true collaboration of various Anatolian peoples. Thus, according to the DTP's analysis, the Turkish Republic has been an anti-democratic state since the 1924 Constitution, which symbolized a "temporal turn" for the Kurdish people whose existence was denied. ${ }^{18}$ The DTP believed that the subsequent constitutions of 1961 and 1982 served to worsen the situation.

On the basis of this premise, the DTP argued that the Kurdish question has been one of Turkey's major problems, and that it could only be solved through extensive and real democratization. Rejecting a separatist agenda, the DTP claimed to be struggling to "establish the brotherhood of peoples and democratic co-existence on the basis of equality and freedom" (DTP, Party Program 16). ${ }^{19}$ However, it is hard to see any consistency in terms of the solutions it offered. Its demands for democratization of the Turkish Republic occasionally referred to a federation of Turks and Kurds, thus an ethnically re-structured state, or to gaining cultural and language rights within the unitary state structure (DTP, Party Program 34; DTP, Democratic Society Party's Project 50-55). Its project of a democratic solution to the Kurdish question was eventually concretized as "democratic autonomy." In accordance with the policy of democratic autonomy, the DTP's goal of democratization of the republic is based on a kind of territorial autonomy as well as the constitutional recognition of the Kurdish people through a series of cultural and political rights, especially education in the Kurdish language (DTP, Democratic Society Party's Project). Regarding state institutions, the party argued that the over-centralized Turkish political and administrative system should be subject to a process of devolution towards a comprehensive regionalization. Regions, including the region of "Kurdistan" in southeastern Anatolia, should have regional parliaments formed through elections. They should be competent in all areas except for foreign affairs, defense, and finance, and they should share authority with central government in the judiciary and police services. Organized as people's assemblies, these parliaments should also enable real participatory democracy (DTP, 2nd Extraordinary Congress Final Declaration). ${ }^{20}$

The DTP has adopted various electoral strategies in order to attain its goals. The DTP received a significant percentage of Kurdish votes in Turkey, concentrated in southeastern Anatolia. ${ }^{21}$ Because its supporters are regionally concentrated, the DTP, like its predecessors, has maintained a strong foothold in local governments - winning, in this case, nine provincial municipalities. ${ }^{22}$ Until 2007, local governments were the center of the DTP's sub-state nationalist politics, but when the party managed to enter the Turkish Parliament by surmounting the national election threshold obstacle indirectly, the DTP parliamentary group became the focus of the party's self-government claims until its closure in $2009 .^{23}$

Compared to its counterparts in the EU, the DTP could only benefit from quite narrow opportunity structures. This resulted not only from state-level constraints but also from 
intra-party cleavages, and its links with the PKK that limited its room for maneuvering. One could argue that the DTP emerged as an outcome of the Kurdish nationalist movement yet suffered from being a movement party. ${ }^{24}$ That is, as a movement party, it has been a coalition of political activists who have diverged on the proper solutions to the Kurdish question and the best political strategies to pursue. The party can also be characterized as an alliance of "doves" and "hawks," with the former advocating a solution to the Kurdish question within a unitary state system, and the latter insisting on Kurdish democratic autonomy. While the doves have been condemned by the hawks as pacifist and conciliatory, the doves have criticized the hawks for pursuing an ethnically-based federation ("DTP'de Nurettin Demirtaş"). Such intra-party cleavages essentially prevented the party from developing a complete, stable collective preference schedule. Furthermore, because it was never transformed fully into an institutionalized political party, the DTP conducted dual-track activism by combining activities within the arenas of formal democratic competition with extra-institutional mobilization. Thus, it became an ordinary sight to witness DTP legislators debate bills in parliamentary committees one day, and participate in disruptive demonstrations the next.

The DTP's other main problem was that it suffered from an inability to distance itself from the PKK. The DTP's leadership occasionally stressed that the party had common grassroots with the $\mathrm{PKK}^{25}$ and called on the state to negotiate with the PKK to solve the Kurdish question. However, this undermined the reason for their autonomous existence in parliament. For instance, Emine Ayna, the DTP deputy leader, clearly stated that the state's real interlocutor regarding the Kurdish issue was the PKK, demanded a general amnesty for all PKK militants, including Öcalan, and suggested that the PKK had to be invited to take its place in the Turkish parliament if the government was sincere about finding a solution. ${ }^{26}$ Indeed, despite his imprisonment, Öcalan has kept his significance for the Kurdish nationalist movement in Turkey. As a part of this movement, the DTP also frequently referred to his "leadership." While the party's "Mr. Öcalan" policy underlined its link with the PKK, ${ }^{27}$ some of party supporters' revealing posters of Öcalan in DTP congresses became one of the main elements of their symbolic struggle against the state. Even though it is incorrect to see the DTP as the political wing of the PKK, there is nevertheless some kind of link between the two. ${ }^{28}$ This link with the PKK has not only put extra constraints upon the party in a relatively narrow political opportunity structure, it has also become one of the major hindrances to further democratization steps in Turkey.

\section{The EU as an external support system for the DTP}

Two basic facts determined the limits of EU support for the DTP's sub-state nationalism. First, since Turkey is not a member state of the EU, the DTP was deprived of many channels open to other sub-state nationalist parties in member states. Secondly, there are no established regional authorities through which the DTP could differentiate itself from other regions at the national or EU level. Thus, unlike its many counterparts in EU countries, the DTP lacked a favorable institutional framework for both paradiplomacy and transnational cooperation with other sub-national actors in the EU. ${ }^{29}$

Nevertheless, it is still reasonable to argue that the DTP benefited from the EUanchored democratization reform process in Turkey. While party members rightly claimed that any solution to the Kurdish question could be solved within domestic dynamics ${ }^{30}$ the DTP also stressed the importance of the EU membership process for the general purpose of democratization in the country (DTP, 2nd Extraordinary Congress Final Declaration). In line with this assessment, through a declaration just before the 
European Council meeting in December 2004, a group of Kurdish intellectuals and politicians, including some members of DEHAP who later participated in the establishment of the DTP, expressed various demands to the Turkish state. Defining the Kurdish question as a fundamental problem hindering Turkey's accession to the EU, the declaration emphasized that "Turkey must guarantee its Kurdish citizens the same rights the Basques, Catalans, Scots, Lapps, South Tyroleans and Walloons enjoy in the democratic countries of Europe, ... a new and democratic constitution, recognizing the existence of the Kurdish people, and guaranteeing it the right to a public school system and media in its own language and the right to form its organizations, institutions and parties with the aim of contributing to the free expression of its culture and its political aspirations." ${ }^{, 31}$ This declaration clearly showed early expectations from Turkey's EU integration process. There is no doubt that since then, democratization reforms have provided the Kurdish movement, specifically the DTP, with new and genuine political opportunities.

In the 1990s, governments occasionally mentioned the "Kurdish reality" in Turkey, and the need for a peaceful solution to it. One political leader, Mesut Yilmaz, even made a clear connection between finding a democratic solution to the Kurdish question and Turkey's accession to the EU. ${ }^{32}$ However, such statements did not yield any palpable results. Unlike these fruitless expressions of the 1990s, AKP governments, especially between 2002 and 2004, implemented critical political reforms in the name of Turkey's EU bid. Consequently, democratization reforms as a part of the Europeanization process have both directly and indirectly affected perceptions and definitions of Turkey's Kurdish issue.

Recognizing that the PKK's violent strategy empowers the same status quo-oriented actors who are also opposed to the AKP, and using the opportunity to end large-scale conflict in southeastern Turkey following the capture of Öcalan, the AKP government redefined the Kurdish question primarily as a problem of democracy rather than security. This crucial step of desecuritizing the issue conformed with the party's comprehensive attempts to civilianize Turkey's political system. Various EU-anchored democratization reform packages lifted the state of emergency that had been in force in southeastern provinces since 1987, and dramatically reduced the power of the National Security Council through which the military had been able to exert a strong political influence. As well as curtailing the military's effect on political life to a remarkable degree, the AKP government's reform packages also allowed some significant individually-based cultural rights for the Kurds. These reforms mainly extended cultural rights by enabling education and broadcasting in Kurdish. On the other hand, these amendments failed to abolish the village guard system, permit Kurdish as a language of instruction in public schools, or reduce the $10 \%$ threshold for general elections. Even so, the reforms have been of great significance since they reflect a paradigmatic change in the Turkish state's view of the Kurdish issue. Despite significant constraints, such as a clear ban on ethno-politics in the Parliament, these reforms have paved the way for allowing the representation of Kurdish demands by a pro-Kurdish political party in the national assembly for the first time in republican history. Therefore, it was no less important that a pro-Kurdish political party, the DTP, was able to form a parliamentary group in the national assembly in 2007 thanks to the relatively more democratic atmosphere, at least compared to previous years when it was taboo even to speak of Kurdish identity or the Kurdish question.

Deprived of the opportunity structures provided by EU institutions, the DTP frequently sought to make use of the Congress of Local and Regional Authorities in the Council of Europe, where it was able to articulate its demands in the Congress loudly and to attract the Congress's attention to the ban on multi-lingual municipal services presented by 
Diyarbakir Sur Municipality and subsequent prosecutions by the Turkish state. The Congress formed a fact-finding mission (Bureau of the Congress) to investigate local democracy and the situation in Sur Municipality, after which it prepared detailed recommendations to Turkey. ${ }^{33}$

Despite its continued significance for the DTP, the EU gradually lost its status as primary external support system for various reasons. First, because the PKK has been on the EU's terrorist organizations list, European countries demanded that the DTP declare it would cut its links with the PKK, ${ }^{34}$ which the party could not accept. The EU's demand, in line with Turkey, that the DTP denounce PKK terrorism led the party to question what the EU could contribute to its strategy. ${ }^{35}$ The EU's vagueness regarding its solutions to the Kurdish question may not have eventually conflicted with the DTP's territorial autonomy-based solution. However, the EU's policy of viewing the PKK as a terrorist organization was apparently incompatible with the DTP's perspective. Second, Turkey's EU accession negotiation process was losing impetus, and it was unclear whether Turkey would eventually become an EU member, since the process had been defined as open-ended in the 2004 European Council meeting. This open-endedness has not only negatively affected Turkish efforts towards democratization; for the DTP, it has also decreased the credibility of the EU's perspective. More critically, empowerment of Kurdish regional autonomous authority in northern Iraq by Western powers has contributed to the revitalization of the ideal of a Greater Kurdistan, ${ }^{36}$ or at least it has broadened the opportunity structures so as to force the Turkish state to become more accepting of Kurdish demands within Turkey. ${ }^{37}$

In sum, EU-anchored democratization reforms have brought about an unprecedented change in Turkey's political system. ${ }^{38}$ Although certain constraints remain for proKurdish politics, the opportunity structures have broadened to include the recognition of Kurdish identity with the provision of a number of cultural rights by the Turkish state. While the party supported the EU as an external support system, the EU implicitly demanded that the DTP turn into a truly institutionalized political party that competed for elections. As it turned out, the DTP, like its predecessors, was unable to survive very long. Its closure in 2009 by the Constitutional Court of Turkey has not only highlighted the continuing difficulties facing Kurdish nationalists, but it has also raised questions about the true depth of the apparent transformation of Turkey's political system towards a more democratic structure.

\section{Concluding remarks}

The contentious relationship between sub-state nationalism and the nation-state has become more intricate within the European integration process, which provides a new opportunity structure for sub-state nationalist political parties. Although the great majority of these political parties uphold the process, their support should not be seen as constant and unconditional. The European integration process serves as an external support system to enrich sub-state nationalist strategies. In the same way, the DTP, as a sub-state nationalist political party, supported the EU integration process for offering external support to broaden the party's opportunity structures. The analysis made here shows that the EU's impact on the DTP's nationalist politics has been indirect and limited. It is true that the DTP was able to obtain relatively broadened opportunity structures as Turkey has undergone reform to meet the Copenhagen criteria in the post-Helsinki process. However, the EU's impact on the party has been predictably limited. Because Turkey is not a member state of the EU, the DTP lacked many of the channels 
open to other sub-state nationalist parties in member states. Furthermore, Turkey still has a highly centralized politico-administrative system that lacks established regional authorities through which the DTP could differentiate itself from other regions at the national and EU levels.

The DTP sought to make use of various platforms in European political architecture and civil society to attract attention to the Kurdish question in Turkey and get political support for the Kurdish nationalist cause, especially in 2004 and 2005. However, the EU integration process did not create sufficient transformation in the party to allow it to denounce the PKK's violent strategy. While the party articulated self-government claims within an individual rights-based perspective and a post-industrial agenda, thus enhancing its social democratic stance, it ignored the EU's calls for the party to explicitly denounce PKK's violent strategy. Hence, the EU gradually ceased to be of primary significance as an external support for the DTP.

Within the context of the opportunity structure model, the European integration process as an external factor has provided the DTP with some significant benefits. However, the failure of the AKP's "Kurdish opening," the DTP's inaction in this process, and the eventual closure of the party show that there are serious constraints at internal and state levels on the opportunity structure that hinder the taking of significant steps towards a solution to the Kurdish question and the legal political representation of Kurdish nationalism.

Recognizing the Kurdish question as the major problem of Turkey, the AKP started an initiative in August 2009 that has been the most courageous attempt to address the problem so far. At first called the "Kurdish opening," this was renamed the "national unity project" due to criticisms from different strands of Turkish nationalism. Besides policies to provide more capital to the region to improve economic development, and enhancement of Kurdish cultural rights, the most assertive aim of the "Kurdish opening" was the disarming and disbanding of the PKK to terminate the Kurdish insurgency.

Unfortunately, the "Kurdish opening" soon failed. Having been unable to develop policies independently from the PKK, the DTP and its successor BDP have shown the PKK as the true interlocutor in negotiations on the Kurdish issue, thereby undermining their own existence as legitimate political entities. Despite aiming to eventually disband the PKK, the AKP has consistently rejected the idea of negotiating with it, as this would equate to political suicide for the party. The DTP could have been a mediator between the PKK and the state, but this might have led to recognizing the AKP's significance in Kurdish constituencies. The "Kurdish opening" failed not only because the exclusion of Kurdish nationalists decreased any chance of a comprehensive solution, but also because of fierce reactions from both opposition parties and within the AKP's own constituencies. This led the party to abandon the political risk of continuing the opening on the eve of the 2011 general elections, which would have critical consequences in terms of drafting a new constitution and holding presidential elections. Furthermore, the AKP found decreasing the $10 \%$ national electoral threshold to be against its interests, as such a reform could have been used by the opposition to claim that the AKP had facilitated the involvement of Kurdish nationalists in the Parliament. At the same time, it would have diluted the AKP's majority by allowing more parties to gain parliamentary representation. Eventually, fading prospects for full membership to the EU, the fierce reaction from the opposition and large sections of electorates conditioned for decades to view the question as just a matter of terrorist separatism, and pragmatist political calculations on the eve of the elections all combined to discourage the AKP from taking decisive steps in its ambiguously defined "Kurdish opening." 39 Accordingly, during its general electoral 
campaign in 2011, the AKP promoted "one state, one flag, one language" - in complete contradiction to the "democratic autonomy" policy of Kurdish nationalists.

Ironically, the AKP's "Kurdish opening" coincided with the closure of the DTP by the Constitutional Court of Turkey on 11 December 2009. The Court decided to close down the party for becoming a "focal point of activities against the indivisible unity of the state, the country, and the nation." ("Anayasa Mahkemesinin"). ${ }^{40}$ The failure of the AKP's "Kurdish opening" and the closure of the DTP have together shown that even when Kurdish nationalists try to act through legal politics within the Turkish political system they still face a highly narrow opportunity structure that is critically shaped by statelevel and internal factors.

\section{Notes}

1. The type of electoral system is a major factor in determining the type of political party system. While proportional representation would benefit sub-state nationalist political parties by raising their parliamentary representation, in majoritarian systems voters may refrain from voting for parties that are unlikely to win any seat (Catt and Murphy). In addition to the relative openness or closure of the institutionalized political system, the state's capacity and propensity for repression affects opportunity structures. McAdam et al. (10) also note the importance of the presence and stability of elite allies.

2. The Franco dictatorship in Spain and the discovery of oil in Scotland can be given as examples of fomenting factors from different contexts (see Saylan).

3. As an ethno-political question, it has various dimensions including cultural rights, socioeconomic underdevelopment of largely Kurdish areas (southeastern Turkey), high levels of unemployment, and terrorism (see Keyman).

4. Upon his capture in Kenya, Öcalan was brought to Turkey 16 February 1999. He was sentenced to death; his sentence was later commuted to life-long imprisonment without parole when the death penalty was abolished in Turkey in August 2002.

5. Tocci ("Europeanization in Turkey") convincingly argues that there is no linear relationship between domestic change in Turkey and EU conditionality. She claims that domestic change has been spearheaded by domestic actors that have used and been strengthened by the external EU anchor (see also Ulusoy).

6. The realignment in domestic politics, the increasing effect of a flourishing civil society, and some signs of an alteration in the military's perspective of the Kurdish question (for the signals from the military see Bila).

7. Nevertheless, Turkey has kept its sensitivity about the recognition of any minorities other than those recognized by the Treaty of Lausanne. For example, it only ratified OSCE conventions with certain reservations grounded in this attitude (for details see Sarigil 186-87).

8. The Institute of Living Languages at Mardin Artuklu University, hosting a department of Kurdish as the first institution of Kurdish language at the university level, was opened in 2009.

9. The European Commission's Turkey 2005 Progress Report, Criteria for Membership: Human Rights and Protection of Minorities, states that "The minorities usually associated by the authorities with the Treaty of Lausanne are Jews, Armenians and Greeks. However, there are other communities in Turkey, which, in the light of the relevant international and European standards, could qualify as minorities" (35).

10. For instance, France, Belgium, Greece, the Netherlands, and Luxembourg have not ratified the Convention for the Protection of National Minorities prepared by the Council of Europe since 1995 (see Phillips).

11. For a detailed analysis of political activism in the Kurdish diaspora in Europe, see EccariusKelly.

12. Neither the Turkish Constitution of 1982 nor the Political Party Law allows the establishment of political parties on ethnic or regional grounds.

13. Kurdish nationalist activism is reflected in the workings of human rights organizations, cultural associations, political parties, self-help organizations, local administrations, and movements of different political stripes, ranging from the traditional Left to Islamic movements. Therefore, the Kurdish national movement is wider than the DTP and the PKK. Other than the DTP, the other 
pro-Kurdish political parties are HAK-PAR (Hak ve Özgürlük Partisi, or Rights and Freedom Party) and KADEP (Kadep Katilimci Demokrasi Partisi, or Participatory Democracy Party). Unlike the DTP, both of these parties openly reject the use of violent methods, yet they both back an ethnic-based federation of Turks and Kurds.

14. The population of an ethnic group seeking self-government is often a matter of speculation for competing parties. The numbers, " 40 million Kurds, 25 million of whom live in the territorial boundaries of the Turkish state," were uttered in the author's interview with Ahmet Türk, 21 January 2009. Nevertheless, many public opinion polls show that almost $15 \%$ of the population in Turkey identify themselves as Kurds. According to the results of two different research projects conducted by KONDA, there are nearly 11-12 million Kurds living in Turkey (2 million in Istanbul); see "Kürt Meselesini Yeniden Düşünmek" ["Rethinking the Kurdish Issue"] Konda Reports 2010. http://www.konda.com.tr/tr/raporlar/2010_12-KONDA_Kurt_Mesele sini_Yeniden_Dusunmek.pdf. Web. 18 Jan. 2012; "Kürtler ve Kürt Sorunu" ["The Kurds and the Kurdish Issue"] Konda Reports Nov. 2008. http://www.konda.com.tr/tr/raporlar/2008_11_ KONDA_Kurtler_ve_Kurt_Sorunu.pdf. Web. 18 Jan. 2012.

15. For a detailed analysis of Kurdish intellectuals' efforts to create a Kurdish ethno-history, see Hirschler.

16. For the construction and the use of Newroz as an ideological means for mobilization by Kurdish nationalists, see Aydın.

17. Although the DTP has never expressed irredentist claims, Kurdistan maps used in the party's congresses, meetings or conventions have often displayed a "Greater Kurdistan" that included Kurdish sections of Iraq, Iran, and Syria. For an exemplary incident about the "map dispute" see "Parka Kürdistan Havuzu Yaptırdı." DTP Kayapinar Mayor faced charges DTP Kayapinar Mayor faced charges for for building a Kurdistan-shaped pool. The pool was demolished and its construction also became one of the charges leveled against the party in the subsequent closure case. See also "DTP'nin nevruzunda Kürdistan haritası skandalı" and "Diyarbakır'da tartışmalı harita!"

18. See for instance, DTP Vice President Ayna as quoted in “Ayna: Atatürk'ün Verdiği Sözler Tutulmalı" [the promises given by Atatürk should be kept].

19. The DTP's vision of European integration is consistent with this view. As a left-wing mass party, it supports the idea of a "People's Europe" against the "Europe of businessmen." This emphasis implies not only an egalitarian social understanding, but also a view that European integration is seen as the proper political framework for the peaceful co-existence of peoples in a democratic Europe (DTP, Party Program 49-50).

20. The BDP, current successor to the DTP, continues this policy. Osman Baydemir has recently summarized democratic autonomy as meaning that "the Kurds would have a parliament in southeastern Anatolia and fly their flag next to the Turkish flag". "Baydemir sparks debate with Kurdish 'Kurdish flag' remarks.” Today's Zaman 2 August 2010. Web. Gülten Kışanak, co-chair of the BDP, has stated that the party has been already implementing the model of democratic autonomy in municipalities held by the BDP mayors. She argues that the BDP strengthens civil society in the name of a participatory democracy by establishing women's, youth, and neighborhood assemblies. "A Road Map to Democratic Autonomy." Bianet 5 September 2011. http://bianet.org/english/minorities/132501-a-road-map-to-democratic-autonomy. Web. 18 Jan. 2012.

21. Based on the criterion of "language spoken with mother at home," Çarkoğlu and Kalaycioğlu identified Kurdish electors as making up $12.8 \%$ of total 42 million electors in Turkey in 2007. In other words, there were about five million Kurdish electors in Turkey in 2007. The Independents whose major force behind it was the DTP obtained 1,822,253 votes (5.19\% of total votes) in 2007 elections ("Türkiye Geneli Seçim Sonuçları." http://secim2007.hurriyet. com.tr/partidetay.aspx?pid=1. Web. 18 Jan. 2012) while the party had $5.68 \%$ of total votes with 2,271,566 votes in 2009 local elections ("Seçim 2009." http://www.hurriyet.com.tr/ english/election2009/election.html. Web. 18 Jan. 2012). Even if it is hard to estimate the exact number of Kurdish voters in Turkey, one can still suggest in the light of these figures that votes for the DTP roughly ranged between $35 \%$ and $45 \%$ of all Kurdish votes.

22. The DTP won 99 municipalities in the recent 2009 local government elections. Nine of the 99 are provincial capitals: Diyarbakır, Batman, Hakkari, Iğdır, Siirt, Şırnak, Tunceli, Bingöl and Van ("Election results by provincial assemblies." http://www.hurriyet.com.tr/english/election2009/ election.html. Web. 18 Jan. 2012). 
23. In order to overcome the $10 \%$ national threshold, the DTP formed a platform of independent candidates in the 2007 general elections, winning 21 seats in the Turkish Parliament. As a result, since 2007, the DTP, now the BDP, has had a parliamentary group in the national assembly (see 'Kurumsal Yapı' at http://www.tbmm.gov.tr/arsiv.htm. Web. 18 Jan. 2012). This is the first time in the history of Turkey that a pro-Kurdish political party has formed a parliamentary group.

24. For detailed information about movement parties, see Kitschelt.

25. The statement by Ahmet Türk, the DTP's leader, read: "Tabanımız dağda" ["Our grassroots is in the mountain]." Sabah, 22 April 2006. Web.

26. "Emine Ayna says that the PKK, Öcalan key to peace." Hürriyet Daily News 12 August 2009. Web.

27. To illustrate, the DTP organized a mass meeting in Diyarbakır in 2007 under the name of a "Mr.Öcalan meeting" (Hürriyet, 25 Nov. 2007). DTP MPs often referred to Öcalan as "Mr." in their interviews and speeches to emphasize that they saw him as respectable and key to solving the Kurdish question. To illustrate, Sabahat Tuncel, Istanbul MP of the DTP, said "Sayın Öcalan'ın fikri alınmalı" ["Mr.Öcalan's opinion should be sought"] Yeni Şafak 1 March 2008; Aysel Tuğluk, Diyarbakir MP of the DTP, said "Çözümün muhatabı Sayın Öcalan'dır" ["The addressee for the solution is Mr. Öcalan"] Radikal 28 August 2009. Web.

28. A report prepared by the European Union Institute for Security Studies states that "it is an obvious secret that DTP is connected to PKK in a way, and the PKK is a terrorist organization" ("EU Report: DTP is connected to PKK 'in a way'." http://www.worldbulletin.net/index.php? aType=haberArchive\&ArticleID=8226. Web. 18 Jan. 2012.

29. The DTP had a representation bureau in Brussels that basically lobbied EU institutions about Kurdish rights in Turkey (author's interview with the DTP Brussels representative, Fay1k Yağızay, 2 April 2008, Brussels). The DTP's representation's effectiveness has been highly limited because of unfavorable institutional design in Turkey. Unlike its many counterparts in Brussels, this office was officially unable to represent Kurdish sub-national identity and interests.

30. Author's interviews with Ahmet Türk (DTP's leader) and Bengi Yıldız (DTP's MP for Batman), 21 January 2009, Turkish Grand National Assembly.

31. For the full text of the declaration, see Institut kurde de Paris.

32. "Yilmaz: the road to EU passes through Diyarbakir," Turkish Daily News 17 December 1999. Print. Diyarbakir is a mostly Kurdish-populated province in southeastern Turkey.

33. Although Recommendation 229 does not have any compelling power on Turkey, it is still a valuable document since it shows that Turkey needs to undergo a comprehensive process of decentralization or devolution. "The Congress of Local and Regional Authorities - Recommendation 229 (2007) Local Democracy in Turkey." https://wcd.coe.int/com.instranet.InstraServlet?command=com. instranet.CmdBlobGet\&InstranetImage $=1691602 \&$ SecMode $=1 \&$ DocId $=1167298 \&$ Usage $=2$. Web. 18 Jan. 2012.

34. Interview with the ambassador of Germany to Turkey (see "“PKK ile bağınızı koparmalısınız").

35. DTP MPs occasionally criticized the EU's stance on the Kurdish question. However, the harshest criticisms have come from Öcalan, the PKK's leader, who has been in prison since 1999. His statements since 2005 coincide with the official view of a foreign conspiracy dimension to the Kurdish question. For instance, Öcalan claims that the Kurdish question is a trump card in the hands of Europe. European countries do not really want to see the Kurdish question solved; they carry on policies that contribute to the protraction of the conflictual situation. Europe is an old enemy of Turkey. Turkey mistakenly believes it can solve the Kurdish question with European assistance. The Europeans wanted to use the PKK, but they were rejected by the PKK; so the Europeans put the PKK on the list of terrorist organizations. "Avrupa Kürt kartını oynuyor" ["Europe plays the Kurdish card"]. Online Gündem 10 February 2007. Web.

36. For instance, the declarations of Kurdish authorities in Northern Iraq regarding the right of Kurds living in neighboring countries to self-determination fueled the debate. Barzani, the president of the Kurdish regional government in Iraq, stated that when the time comes, Kurds in Turkey and Syria would naturally use their right to self-determination. "Saldırı olursa kendimizi koruruz" ["We shall defend ourselves if we are attacked by"]. Hürriyet 3 February 2007. Web. This pan-Kurdish perspective of the Kurdish authorities in Iraq was also accompanied by declarations by DTP representatives emphasizing a pan-Kurdish solidarity. For instance, against the possibility of Turkish military intervention in Kirkuk, the DTP's Diyarbakir 
branch leader declared that any attack on Kirkuk would be tantamount to an attack on Diyarbakir. "Kurdish leader charged with controversial remarks." Turkish Daily News 24 February 2007. Web.

37. In the volatile circumstances of the region, Turkey has gradually changed its policy with respect to the Kurdish regional government in Northern Iraq, which has brought about an apparent improvement in relations. Consequently, the Kurdish authorities emphasized the importance of maintaining good relations with Turkey by gradually playing down the pan-Kurdish dimension of their policies.

38. Turkish governments have occasionally made declarations about a "Kurdish reality" and the importance of finding a democratic solution to the Kurdish question in terms of Turkey's EU bid. However, until the recent reforms, none of these declarations had resulted in material actions.

39. One should here mention two recent articles, both of which focus on the failure of the AKP's "Kurdish opening" in interaction with the process of Europeanization in Turkey. Kirişci rightfully argues that as the EU's engagement with Turkish full membership has been weakened, the EU has gradually lost its transforming capacity on Turkish politics, including on the Kurdish question. Thus, reform-minded political and social actors, most importantly the governing party, have become deprived of a critical support in facing the rising nationalist backlash in Turkey against the EU-anchored political efforts to find a democratic solution to the Kurdish question. In the same way, Somer and Liaras emphasize EU-related causes as a significant factor for fierce reaction from both the opposition and the government's own constituencies to the "Kurdish opening." Differently, they observe a limited amount of normative change on the Kurdish question among religious conservatives, largely represented by the AKP, despite the party's reformist image.

40. On its closure, the ex-DTP MPs, except for the two having lost their MP status (Ahmet Türk and Aysel Tuğluk), joined the Peace and Democracy Party (Barış ve Demokrasi Partisi, BDP), which is the current successor to the DTP.

\section{References}

Akyol, Mustafa. Kürt Sorununu Yeniden Düşünmek [Rethinking the Kurdish Question]. İstanbul: Doğan Kitap, 2006. Print.

Aydın, Delal. "Mobilizing the Kurds: Newroz as a Myth." Master's thesis, Middle East Technical University, 2005. Print.

“Ayna: Atatürk'ün Kürtlere verdiği söz tutulsun" [Ayna: The promises given by Atatürk should be kept]. Radikal, 11 July 2009. Web. 7 Jan. 2012. < http://www.radikal.com.tr/Radikal. aspx ?aType $=$ RadikalDetay \&ArticleID $=944628 \&$ Date $=13.07 .2009 \&$ CategoryID $=78>$.

“Anayasa Mahkemesinin E: 2007/1 (Siyasi Parti-Kapatma), K: 2009/4 Sayılı Kararı." T.C. Resmi Gazete, 14 Dec. 2009. Web. 7 Jan. 2012. <http://www.resmi-gazete.org/rega/ anayasa-mahkemesinin-e-2007-1-siyasi-parti-kapatma-k-2009-4-sayili-karari-5874.htm > .

Beland, Daniel, and Andres Lecours. "Sub-State Nationalism and the Welfare State: Quebec and Canadian Federalism." Nations and Nationalism 12.1 (January 2006): 77-96. Print.

Bila, Fikret. Komutanlar Cephesi [The Commanders' Front]. İstanbul: Detay Yayıncılık, 2007. Print.

Birch, Anthony H. Nationalism and National Integration. London: Unwin Hyman, 1989. Print.

Bozarslan, Hamit. "Why the Armed Struggle? Understanding the Violence in Kurdistan of Turkey." The Kurdish Conflict in Turkey. Ed. Gülistan Gürbey and Ferhad Ibrahim. New York: St.Martin's, 2000: 17-30. Print.

Breuilly, John. Nationalism and the State. 2nd ed. Manchester: Manchester UP, 1993. Print.

Bureau of the Congress. "Local Democracy in Turkey. Situation in Sur/Diyarbakir (South-East Anatolia, Turkey). Report of the Congress Fact-Finding Mission to Turkey (8-10 August 2007)." Strasburg: Congress of Local and Regional Authorities, 2007. Web. 7 Jan. 2012.

Çarkoğlu, Ali, and Ersin Kalaycı̆ğlu. Seçim 2007: Devam Eden Eğilimler mi? Yoksa Yeni Başlangıçlar mı? [Elections 2007: Continuing Trends or New Beginnings?]. İstanbul: Açık Toplum Enstitüsü - Sabancı Üniversitesi, 2007. Print. 
Catt, Helen, and Michael Murphy. Sub-State Nationalism: A Comparative Analysis of Institutional Design. Oxford: Routledge, 2002. Print.

Cizre, Ümit. "Introduction - The Justice and Development Party: Making of Choices, Revisions and Reversals Interactively." Secular and Islamic Politics in Turkey. Ed. Ümit Cizre. London: Routledge, 2008. Print.

Cornell, Svante. "The Kurdish Question in Turkish Politics." Orbis 45.1 (Winter 2001): 31-46. Print.

Csergo, Zsuzsa, and James Goldgeier. "Nationalist Strategies and European Integration." Perspectives on Politics 2.1 (April 2004): 21-37. Print.

De Winter, Lieven. "Conclusion: A Comparative Analysis of Electoral, Office, and Policy Success of Ethnoregionalist Parties." Regionalist Parties in Western Europe. Eds. Lieven De Winter and Huri Türsan. London: Routledge, 1998. Print.

"Diyarbakır'da tartışmalı harita!" CNN Türk, 1 June 2009. Web. 7 Jan. 2012. < http://www. cnnturk.com/2009/turkiye/05/31/diyarbakirda.tartismali.harita/528912.0/index.html >.

DTP (Demokratik Toplum Partisi). 2nd Extraordinary Congress Final Declaration. Ankara November 2007. Print.

- Democratic Society Party's Project of Democratic Solution to the Kurdish Question. Ankara. September 2008. Print.

- Party Program. Ankara, 2005. Print.

“DTP'de Nurettin Demirtaş genel başkan.” NTVMSNBC, 9 Nov 2007. Web. 7 Jan. 2012. $<$ http://arsiv.ntvmsnbc.com/news/425637.asp $>$.

“DTP'nin nevruzunda Kürdistan haritası skandalı.” Zaman Gündem, 21 Mar. 2008. Web. 7 Jan. 2012. < http://www.zaman.com.tr/haber.do?haberno=667543\&title=dtpnin-nevruzundakurdistan-haritasi-skandali $>$.

Eccarius-Kelly, Vera. "Political Movements and Leverage Points: Kurdish Activism in the European Diaspora." Journal of Muslim Minority Affairs 22.1 (2005): 91-118. Print.

EU Commission Progress Reports on Turkey 1998, 2005. Print.

"EU report: DTP is connected to PKK 'in a way'." World Bulletin, 6 Aug. 2007. Web. 7 Jan. 2012. < http://www.worldbulletin.net/news_detail.php?id=8226>.

Guibernau, Montserrat. Nations without States: Political Communities in a Global Age. Oxford: Polity, 1999. Print.

Gürbey, Gülistan, and Ferhad Ibrahim. "Introduction." The Kurdish Conflict in Turkey. Ed. Gülistan Gürbey and Ferhad Ibrahim. New York: St. Martin's, 1999. Print.

Hak ve Özgürlük Partisi. Web. 7 Jan. 2012. < http://www.hakpar.org.tr>.

Hirschler, Konrad. "Defining the Nation: Kurdish Historiography in Turkey in the 1990s." Middle Eastern Studies 37.3 (July 2001): 145-66. Print.

Hooghe, Liesbet. "Nationalist Movements and Social Factors: A Theoretical Perspective." The Social Origins of Nationalist Movements: The Contemporary West European Experience. Ed. John. W. Coakley. London: Sage, 1992. Print.

Institut kurde de Paris. "What do the Kurds Want in Turkey?" 8 Dec. 2004. Web. 7 Jan. 2012. $<$ http://www.institutkurde.org/activites_culturelles/appels/what_do_the_kurds_want_in_ turkey/>.

Jackson Preece, Jennifer. National Minorities and the European Nation-States System. Oxford: Clarendon, 1998. Print.

Kadep Katilimci Demokrasi Partisi. Web. 7 Jan 2012. < http://www.kadep.org.tr>.

Keyman, Fuat E. Türkiye'nin Iyi Yönetimi, Demokratikleşme ve Özgürlükçü Sol Alternatif [Good Governance for Turkey, Democratization and Libertarian Left Alternative]. İstanbul: İstanbul Bilgi U Yayınları, 2008. Print.

Kirişci, Kemal. "The Kurdish Issue in Turkey: Limits of European Union Reform." South European Society and Politics 16.2 (2011): 335-49. Print.

Kitschelt, Herbert. "Movement Parties." Handbook of Party Politics. Eds. R.S. Katz and W. Crotty. London: Sage, 2006. Print.

Lecours, Andre. 2007. Basque Nationalism and the Spanish State. Reno: U of Nevada P. Print. 
Mann, Michael. "Nation-states in Europe and Other Continents: Diversifying, Developing, Not Dying." Daedalus 122.3 (1993): 115-40. Print.

McAdam, Doug, et al. "Introduction: Opportunities, Mobilizing Structures, and Framing Processes - toward a Synthetic, Comparative Perspective on Social Movements." Comparative Perspectives on Social Movements. Eds. Doug McAdam, John D. McCarthy, and Mayer N. Zald. Cambridge: Cambridge UP, 1996. Print.

McDowall, David. A Modern History of the Kurds. 3rd ed. London: Tauris, 2004. Print.

Newman, Saul. "Does Modernization Breed Ethnic Conflict?" World Politics 43.3 (April 1991): 451-78. Print.

Oran, Baskın. Türkiye'de Azınlıklar. İstanbul: İletişim Yayınları, 2004. Print.

Özcan, Ali Kemal. Turkey's Kurds: A Theoretical Analysis of the PKK and Abdullah Öcalan. Oxon: Routledge, 2006. Print.

"Parka Kürdistan Havuzu Yaptırdı.” Aktif Haber, 24 Feb. 2007. Web. 7 Jan. 2012. < http:// www.aktifhaber.com/parka-kurdistan-havuzu-yaptirdi-103381h.htm $>$.

Phillips, Alan. The Framework Convention for the Protection of Minority Rights: A Policy Analysis. Policy paper. Minority Rights Group International, 2002. Web. 3 Jan. 2012.

““PKK ile bağınızı koparmalısınız'." Milliyet, 6 April 2005. Web. 7 Jan. 2012. < http://www. milliyet.com/2005/04/06/yazar/idiz.html>.

"Possible Solution for Kurdish Question Suits EU Accession Process." Bianet, 1 July 2010. Web. 7 Jan. 2012. < http://bianet.org/english/local-goverment/123087-possible-solutionfor-kurdish-question-suits-eu-accession-process $>$.

"Pro-Kurdish politics unite under Zana's DTH." Hurriyet Daily News, 18 Aug. 2005. Web. 7 Jan. 2012. <http://www.hurriyetdailynews.com/h.php?news=pro-kurdish-politics-uniteunder-zanas-dth-2005-08-18>.

Sarıgil, Zeki. "Endogenizing Institutions." Ph.D. thesis, U of Pittsburgh, 2007. Print.

Saylan, İbrahim. "Sub-State Nationalism within European Integration Process: A Comparative Study of Basque, Scottish and Kurdish Cases." Ph.D. thesis, Bilkent U, Ankara, Turkey, 2011. Print.

Somer, Murat, and Evangelos Liaras. "Turkey's New Kurdish Opening: Religious versus Secular Values." Middle East Policy 17.2 (2010): 152-65. Print.

Suny, Ronald Grigor. "Globalization and the Nation-State." Paper presented at ASEN Conference on Nationalism and Globalization, London, 31 March-2 April 2009. Paper presentation.

Tarrow, Sidney G. Power in Movement: Social Movements and Contentious Politics. 2nd ed. Cambridge: Cambridge UP, 1998. Print.

Tocci, Nathalie. "Europeanization in Turkey: Trigger or Anchor for Reform?" South European Society and Politics 10.1 (April 2005): 73-83. Print.

- "The Europeanization of Turkey's Kurdish Question." Turkey and the European Union. Ed. Joseph S. Joseph. Basingstoke: Palgrave Macmillan, 2006. Print.

Ulusoy, Kıvanç. "The Challenge to Europeanization to Turkish Politics and Political Structure." CES Working Papers, No. 1. Middle East Technical University, Ankara, 2007. Print. van Houten, Pieter. "Regional Assertiveness in Western Europe: A Statistical Exploration." Paper presented at ECPR Joint Sessions, Center and Peripheries in a Changing World, Grenoble, 6-11 April 2001. Print. Paper presentation.

Yavuz, Hakan M., and Michael Günter. "The Kurdish Nation.” Current History 100. 642 (Jan 2001): 33-39. Print. 